\title{
RESULTS OF URINE DIPSTICK SCREENING TEST IN ELEMENTARY SCHOOL CHILDREN
}

\author{
ILKÖĞRETIM ÇAĞINDAKI ÇOCUKLARDA IDRAR DIPSTICK TARAMA TESTI \\ SONUÇLARI
}

\author{
Günay MURADOVA ${ }^{1}$, Zeynep YÜRÜK YILDIRIM² (D), Özde Nisa TÜRKKAN² (D), Ahmet NAYIR² (D) \\ Istanbul University, Istanbul Faculty of Medicine, 'Department of Pediatrics, ${ }^{2}$ Department of Pediatric Nephrology, Istanbul, Turkey
}

ORCID IDs of the authors: G.M. 0000-0001-8211-1182; Z.Y.Y. 0000-0003-2891-2231; Ö.N.T. 0000-0003-2928-9031;

A.N. 0000-0002-3357-9237

Cite this article as: Muradova G, Yuruk Yildirim Z, Turkkan ON, Nayir A. Results of urine dipstick screening test in elementary school children. J Ist Faculty Med 2020;83(3):254-8. doi: 10.26650/IUITFD.2019.0037

\section{ABSTRACT}

Objective: Renal diseases may present with proteinuria, hematuria and pyuria without any symptoms. The aim of the study is to determine of urinalysis abnormalities by urine dipstick screening program in healthy school-aged children.

Material and Method: We evaluated results of urine dipstick tests of 1052 children (541 male, 511 female) between the ages of 9 and 10. A second urine dipstick test was performed on those students who had hematuria and/or proteinuria in the first test.

Results: Abnormality in urine dipstick test was detected in a total of $137(13 \%)$ children. Sixteen cases had isolated hematuria (1.5\%), 22 cases isolated proteinuria (2.1\%) and one case $(0.1 \%)$ combined hematuria-proteinuria. In the second evaluation with the dipstick test, we determined that hematuria persisted only in $8(0.8 \%)$ and proteinuria in 2 cases $(0.2 \%)$. Additionally, 96 cases (9.1\%) were positive for leucocyte-esterase, and 18 cases (1.7\%) were nitrite positive in the first screening.

Conclusion: Our findings revealed that prevalence of hematuria and proteinuria was reduced in the second urine dipstick screening. Therefore, asymptomatic patients with isolated proteinuria or hematuria should be re-evaluated with a urine dipstick. Our study suggests that with the help of screening tests in schoolaged children; hematuria, and proteinuria can be determined and this might be an indication for the asymptomatic period of a kidney disease.

Keywords: Children, dipstick, hematuria, proteinuria, screening, urinalysis

\section{ÖZET}

Amaç: Renal hastalıklar herhangi bir semptoma neden olmadan hematüri ve proteinüri ile ortaya çıkabilirler. Çalışmamızın amacı sağlıklı, okul çağındaki çocuklarda idrar analizi anormalliklerinin idrar dipstick testi ile değerlendirilmesidir.

Gereç ve Yöntem: Yaşları 9-10 aralığında olan 1052 (541, erkek 511 kız) çocuğun idrar dipstick test sonuçları değerlendirildi. illk idrar analizinde anormallik tespit edilen çocuklarda kalıcı hematüri ve proteinürinin değerlendirilmesi için ikinci bir idrar dipsitick testi yapıldı.

Bulgular: Anormal idrar dipstick test sonucu 137 (\%13) hastada tespit edildi. On altı $(\% 1,5)$ çocukta izole hematüri, $22(\% 2,1)$ çocukta izole proteinüri ve bir $(\% 0,1)$ çocukta kombine hematuria ve proteinuri tespit edildi. İinci idrar dipsitick testinde hematürinin yanlızca 8 çocukta $(\% 0,8)$ ve proteinurinin $2(\% 0,2)$ çocukta persiste ettiği görüldü. Ayrıca ilk idrar analizinde 96 $(\% 9,1)$ çocukta lökosit esteraz pozitifliği, $18(\% 1,7)$ çocukta nitrit pozitifliği, $10(\% 0,95)$ çocukta hem lökosit esteraz hem de nitrit pozitifliği tespit edildi.

Sonuç: Çalışmamızın sonuçlarında ikinci bir idrar analizi yapıldığında hematüri ve proteinüri sıklığının düştüğü görülmüştür. Bu nedenle izole hematüri ya da proteinüri saptanan asemptomatik hastalar ikinci bir idrar analizi ile yeniden değerlendirilmelidir. Çalışmamızın sonuçları okul çağı çocuklarında dipstick tarama testi ile hematüri ve proteinüri tespit edilebileceğini ve bu durum böbrek hastalıklarının asemptomatik döneminin bulgusu olabileceğini göstermektedir.

Anahtar Kelimeler: Çocuk, dipstick, hematuri, proteinüri, tarama, idrar analizi

Corresponding author/iletişim kurulacak yazar: znyuruk@gmail.com

Submitted/Başvuru: 13.05.2019 • Revision Requested/Revizyon Talebi: 18.09.2019 •

Last Revision Received/Son Revizyon: 18.11.2019 • Accepted/Kabul: 02.01.2020 • Published Online/Online Yayın: 11.02.2020

(C)Telif Hakkı $2020 \mathrm{~J}$ Ist Faculty Med - Makale metnine jmed.istanbul.edu.tr web sayfasından ulaşılabilir.

CCopyright 2020 by J Ist Faculty Med - Available online at jmed.istanbul.edu.tr 


\section{INTRODUCTION}

Renal diseases may present with proteinuria, hematuria and pyuria and patients may not show any symptoms (1). Therefore, diagnosis and treatment might be delayed for such patients. Diagnosis of kidney diseases by routine urine screening programs before the symptomatic period may prevent or delay the progression of chronic kidney diseases (CKD) to end-stage renal disease (ESRD) (24). The urine dipstick test is the most common, practical and sensitive screening method for the early diagnosis of a kidney disease by determining erythrocyte, leukocyte, nitrite and protein in urine $(1,5,6)$. Additionally, urine $\mathrm{pH}$ and specific gravity evaluation by urine dipstick test provide information about the status of hydration and nutritional habits of children.

Isolated proteinuria or hematuria is often transient and indicates mostly an underlying benign disorder. However, when albuminuria, and urine sediment abnormalities persist more than 3 months, patients are accepted as CKD according to the KDIGO guideline (7). Therefore, the children with persistent proteinuria or hematuria must be evaluated further and followed in case of progression to CKD. To determine and evaluate hematuria and proteinuria, the urine dipstick test is an inexpensive and practical tool to use.

The aim of the study was to screen healthy school aged children by urine dipstick test to determine proteinuria and hematuria, and thereby determine the prevalence of the patients who are at risk of progression to CKD.

\section{MATERIAL AND METHOD}

Between December 2016 and January 2017, 1052 students in $4^{\text {th }}$ and $5^{\text {th }}$ grades of 7 schools in Istanbul were enrolled in the study. This study was approved by the local ethical committee (No: 2016/1341) and written informed consent was obtained from the children's parents. Non-voluntary children (despite parental approval) and children with any acute and chronic disorder during the study were excluded from the study.

At least $2 \mathrm{ml}$ of urine were obtained for urinalysis by urine dipstick test. Urinalysis was performed within 0.5-1 min after urine collection in a mobile laboratory.
Urine $\mathrm{pH}$, specific gravity, protein, hemoglobin, glucose, ketone, acetone, bilirubin, urobilinogen, nitrite and leucocyte were determined by immersion method in urine with urine dipstick test (URIT 11G brand). Within one month, a second urinalysis with the same procedure was performed in children who had hematuria and/ or proteinuria according to the first urinalysis. Written information was given to the parents of the children who had abnormal urinalysis during the first and second test, and recommended to apply to outpatient clinic for the further evaluation.

Statistical calculations were performed with IBM SPSS Statistics for Windows, Version 24.0. Armonk, NY: IBM Corp. Besides standard descriptive statistical calculations (mean, standard deviation, median, and IQR), the chi-square test was used for comparisons of qualitative variables. Statistical significance level was established at $p<0.05$.

\section{RESULTS}

The gender distribution and grade of children were given in Table 1.

\section{First urinalysis results}

Urine abnormalities were detected in 137 (13\%) children according to the first urinalysis results. Hematuria was detected in 16 (1.5\%), proteinuria in 22 (2.1\%), leukocyte esterase positivity in $96(9.1 \%)$, nitrite positivity in 18 (1.7\%), ketone bodies in $1(0.1 \%)$ of the children. Urine abnormality was higher in the $5^{\text {th }}$ grade children than the $4^{\text {th }}$ grade children (16.3\% vs $13.9 \%$, respectively).

The hematuria and proteinuria prevalence according to gender and grade of children were given in Table 2. There was no difference between males and females in terms

Table 1: The distribution of gender and grade of children

\begin{tabular}{lccc}
\hline & \multirow{2}{*}{ Total n (\%) } & \multicolumn{2}{c}{ Gender } \\
\cline { 3 - 4 } & & Female n (\%) & Male n (\%) \\
\hline & $\mathbf{1 0 5 2 ( 1 0 0 \% )}$ & $\mathbf{5 1 1 ( 5 1 . 4 \% )}$ & $\mathbf{5 4 1 ( 4 8 . 6 \% )}$ \\
$\mathbf{4}^{\text {th }}$ grade & $835(79.4 \%)$ & $423(40.2 \%)$ & $412(39.2 \%)$ \\
$\mathbf{5}^{\text {th }}$ grade & $217(20.6 \%)$ & $118(11.2 \%)$ & $99(9.4 \%)$ \\
\hline
\end{tabular}

Table 2: Prevalance of hematuria and proteinuria in the first and second urine dipstick screening

\begin{tabular}{|c|c|c|c|c|c|}
\hline & \multicolumn{2}{|c|}{ First dipstick screening } & \multicolumn{3}{|c|}{ Second dipstick screening } \\
\hline & Female n (\%) & Male n (\%) & $P^{*}$ & Female n (\%) & Male n (\%) \\
\hline Isolated proteinuria & $11(1.0)$ & $11(1.0)$ & 0.163 & 0 & $2(0.2)$ \\
\hline Isolated hematuria & $14(1.3)$ & $2(0.2)$ & 0.825 & $7(0.7)$ & $1(0.1)$ \\
\hline Combined hematuria and proteinuria & $1(0.1)$ & 0 & & 0 & 0 \\
\hline
\end{tabular}


of isolated proteinuria and hematuria $(p=0.163, p=0.825$, respectively, Table 2). Combined hematuria and proteinuria was detected only in a $4^{\text {th }}$ grade girl $(0.1 \%)$.

All children with leukocyte esterase and nitrite positivity were female. Ten $(0.95 \%)$ children had both leukocyte esterase and nitrite positivity.

Urine specific gravity of the children ranged from 10101030. There were no children who had hypostenuric urine $(<1010)$. Isostenuric urine (specific gravity: 1010-1020) was detected in $30.8 \%$ of the cases and hyperstenuric urine (specific gravity: $>1020$ ) was detected in $69.2 \%$ of the cases (Figure 1).

Urine $\mathrm{pH}$ of the children was ranged between 5-5.5. Eight $(0.8 \%)$ children had alkaline urine.

\section{Second urinalysis results}

A second urine dipstick test was performed to determine the prevalence of persistent hematuria and proteinuria in the study subjects. Urinary abnormality was detected in only 12 children (1.14\%) in the second urinalysis by urine dipstick test. Proteinuria was detected only in 2 (9.1\%) boys among 22 children with proteinuria on the initial screening. The persistent proteinuria prevalence was $0.2 \%$. Hematuria was detected in 8 (50\%) children (7 female, 1 male) among 16 children with hematuria on the initial screening. The persistent hematuria prevalence was $0.8 \%$. The second urine dipstick test was normal in the patient with combined hematuria and proteinuria according to the first urine dipstick test.

\section{DISCUSSION}

The urine dipstick test is a non-invasive, useful, inexpensive diagnostic tool which provides important clues of kidney as well as other organ disorders. It has been

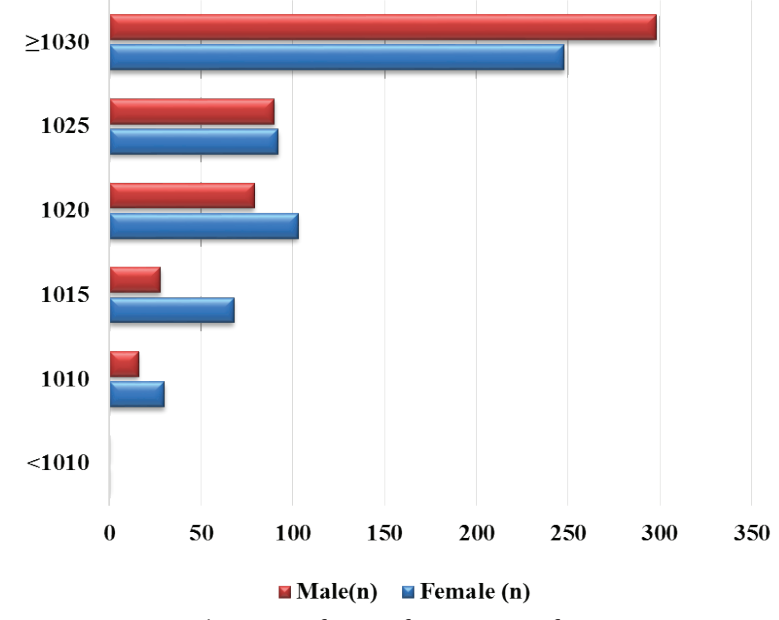

Figure 1: Distribution of specific gravity of urine. considered that urinalysis is an important method for the early detection of kidney diseases since they may be asymptomatic in the early period. However, the necessity of routine urinalysis screening is still controversial. Until 2007, the American Academy of Pediatrics (AAP) recommended routine urine analysis even in healthy children (8). However, the AAP published in 2007 that the routine dipstick urinalysis is only recommended in children at higher risk for CKD (8).

Hematuria and proteinuria can be easily detected by urinalysis and can occur due to a variety of disorders. Hematuria or proteinuria can appear as an incidental finding. One of the most powerful predictors of impaired renal function is the degree of proteinuria (9-11). Proteinuria screening may be a better indicator in determining the risk of developing chronic renal failure than the screening of reduced renal function $(1,12)$.

Prevalence of hematuria and proteinuria were demonstrated between 1.3-13.3 and 0.23-8.7\% in different regions of our country (13-17). In our study, we demonstrated a prevalence of hematuria and proteinuria of 1.5\%, $2.1 \%$ respectively in the first urine dipstick screening testing. However, this prevalence was significantly reduced in the second screening as $0.8 \%$ for hematuria and $0.2 \%$ for proteinuria. These rates were lower than the other previous studies conducted in our country (13-17). Our study suggests that asymptomatic patients with isolated proteinuria or hematuria should be re-evaluated to determine whether this condition is transient or not. Therefore, a school urine dipstick screening program should be conducted by two steps, and also asymptomatic children with urinary abnormalities should have a second dipstick testing. Children with persistent proteinuria or hematuria in the second urine dipstick test should be referred to secondary or tertiary centers.

The school urinary screening programs have been performed in several countries, especially in Asian countries due to higher prevalence of glomerulonephritis (5, $10,18,19)$. Japan was the first country to introduce a national urine screening program in school age children (20). The prevalence of hematuria and proteinuria was $0.54 \%$ and $0.08 \%$, and the annual incidence of hematuria, proteinuria and combined hematuria and proteinuria in Japan was found to be $0.19 \%, 0.03 \%$ and $0.02 \%$ respectively in children aged $6-10(21,22)$. It has been stated that the school urinary screening program reduced the number of ESRD due to glomerulonephritis and also increased the age of patients with ESRD (23). In our study, we demonstrated a higher prevalence of hematuria and proteinuria than the Japanese population, even in the second screening. These results suggest that a school urine dipstick screening program may be useful for our country as it is in Japan. In our 
country, the most common cause of end-stage renal disease is CAKUT and the second is glomerulonephritis in children (24). Proteinuria and hematuria can be detected in children with aforementioned renal disease in the asymptomatic period by urine dipstick screening program. Hereby, preventive treatments for progression to ESRD can be provided for these children in the early period.

The hematuria and proteinuria prevalence ranged between 0.02-2.3 and 0.12-1.85 according to urinary screening programs conducted in different countries (10, 26-28). The underlying pathology among these children with persistent hematuria was glomerular origin in 22.5-52.3\% of children according to further evaluation for these children $(10,11,27,28)$. After introducing the school urine dipstick screening program, the incidence of CKD due to focal segmental glomerulosclerosis and systemic lupus erythematosus was decreased in Taiwan (2). Additionally, the number of cases who started dialysis was decreased in five years with the school screening program (2). Genetic renal disorders such as genetic FSGS, which can be insidious, are relatively common in our country due to consanguineous marriages. With the school urinary screening program, these patients will be recognized earlier and the early interventions may delay the progression of CKD to ESRD.

Hyperstenuric urine was demonstrated in $69.2 \%$ of children in the present study. These results suggest that school aged children do not consume enough water. However, this result may be an indirect consequence of poor hygiene in the school lavatory. Especially girls tend to refuse urination in school, and they reduce water intake to avoid using the school lavatory (29). Our results suggest that children should be encouraged to drink more water in terms of kidney health, and free access to clean toilets should be provided. Thus, the incidence of stone diseases and voiding dysfunction will be reduced.

Our study had some limitations. Although, the present study was conducted in the province with largest and most cosmopolite population in our country, it may not reflect the entire population. Further evaluation and long-term follow-up of the patients with urinary abnormalities were not evaluated.

The medical, social and economic burden of CKD has been increasing day by day in the whole world. Therefore, national disease management models should be developed to prevent diseases and the progression of diseases, and to build strategies for early diagnosis and treatment. As in our country and some other countries, well-child care visits can be ignored and disregarded by the parents, especially in school aged children. Therefore, urinary screenings may be a necessary strategy and may be included in our national disease management program. For preventing CKD and for disease management, each country should determine their own strategies. We suggest that urinary screening by urine dipstick test in school aged children is necessary to increase awareness, protect kidney health and reduce the incidence of renal disease for our country. Necessity may be delineated more comprehensively by the introducing a national urine dipstick screening program in school aged children. Additionally, school urine dipstick screening programs should be organized in a two step manner for excluding the transient causes of hematuria and proteinuria and to avoid unnecessary medical testing of the children.

Etik Komite Onayı: Bu çalışma için etik komite onayı Yerel Etik Kurul'ndan alınmıştır (No:2016/1341).

Bilgilendirilmiş Onam: Katılımcılardan bilgilendirilmiş onam alınmıştır.

Hakem Değerlendirmesi: Dış bağımsız.

Yazar Katkıları: Çalışma Konsepti/Tasarım- A.N., G.M.; Veri Toplama- A.N., G.M.; Veri Analizi/Yorumlama- A.N., Z.Y.Y., G.M., Ö.N.T.; Yazı Taslağı- A.N., Z.Y.Y., G.M., Ö.N.T.; İçeriğin Eleştirel incelemesi- A.N., Z.Y.Y., G.M., Ö.N.T.; Son Onay ve SorumlulukA.N., Z.Y.Y., G.M., Ö.N.T.

Çıkar Çatışması: Yazarlar çıkar çatışması beyan etmemişlerdir.

Finansal Destek: Yazarlar finansal destek beyan etmemişlerdir.

Teşekkür: Çocuk Böbrek Vakfı'na bu taramanın gerçekleşmesini sağladıkları için teşekkür ederiz.

Ethics Committee Approval: This study was approved by Local Ethics Committee (No:2016/1341).

Informed Consent: Written consent was obtained from the participants.

Peer Review: Externally peer-reviewed.

Author Contributions: Conception/Design of Study- A.N., G.M.; Data Acquisition- A.N., G.M.; Data Analysis/Interpretation- A.N., Z.Y.Y., G.M., Ö.N.T.; Drafting Manuscript- A.N., Z.Y.Y., G.M., Ö.N.T.; Critical Revision of Manuscript- A.N., Z.Y.Y., G.M., Ö.N.T.; Final Approval and Accountability- A.N., Z.Y.Y., G.M., Ö.N.T.

Conflict of Interest: Authors declared no conflict of interest.

Financial Disclosure: Authors declared no financial support.

Acknowledgement: We would like to thank the Child Kidney Foundation for providing this screening. 


\section{REFERENCES}

1. Yamagata K, Iseki K, Nitta K, Imai H, lino Y, Matsuo S. Chronic kidney disease perspectives in Japan and the importance of urinalysis screening. Clin Exp Nephrol 2008;12:1-8. [CrossRef]

2. Lin CY, Hsieh CC, Chen WP, Yang LY, Wang HH. The underlying diseases and follow-up in Taiwanese children screened by urinalysis. Pediatr Nephrol 2001;16(3):232-7. [CrossRef]

3. Schumann GB, Greenberg NF. Usefulness of macroscopic urinalysis as a screening procedure. Am Soc Clin Pathol 1979;71:452-6. [CrossRef]

4. Shaw ST, Poon SY, Wong ET. Routine urinalysis. Is the dipstick enough? JAMA 1985;253:1596-600. [CrossRef]

5. Koyama A, Igarashi M, Kobayashi M. Naturals history and risk factors for immunoglobulin A nephropathy. Am J Kid Dis. 1997;29:526-32. [CrossRef]

6. Kemper KJ, Avner ED. The case against screening urinalyses for asymptomatic bacteriuria in children. Am J Dis Child 1992;146:34346. [CrossRef]

7. Stevens PE, Levin A. Evaluation and management of chronic kidney disease: synopsis of the kidney disease: improving global outcomes 2012 clinical practice guideline. Ann Intern Med 2013;158(11):825-30. [CrossRef]

8. Recommendations for Preventive Pediatric Health Care. Pediatrics, 2007;120(6):1376. [CrossRef]

9. Lin CY, Sheng CC, Chen CH, Lin CC, Chou P. The prevalence of heavy proteinuria and progression risk factors in children undergoing urinary screening. Pediatr Nephrol 2002;14:9539. [CrossRef]

10. Murakami M, Yamamoto H, Ueda Y, Murakami K, Yamauchi K. Urinary screening of elementary and junior high-school children over a 13-year period in Tokyo. Pediatr Nephrol 1991;5:50-3. [CrossRef]

11. Cho BS, Kim SD, Choi YM, Kang HH. School urinalysis screening in Korea: prevalence of chronic renal disease. Pediatr Nephrol 2001;16:1126-8. [CrossRef]

12. Halbesma N, Kuiken DS, Brantsma AH, Bakker SJ, Wetzels JF. De estimated GFR to identify individuals at risk for accelerated GFR loss in population screening. J Am Soc Nephrol 2006;17:2582-90. [CrossRef]

13. Yayli G, Yaman H, Demirdal T. Asymptomatic bacteriuria rates in schoolchildren: results from a rural city in Turkey. $J$ Trop Pediatr 2003;49:228-30. [CrossRef]

14. Yenisay C, Sonmez F. Aydın'da okul çağı çocuklarında asemptomatik hematüri, proteinüri, pyüri taraması. Adnan Menderes Ünv Araştırmaları, 1999.

15. Mir S, Keskinoglu A, Ozkayın N, Ozdemir O. Illkokul 1. Sınıf çocuklarında asemptomatik idrar yolu enfeksiyonu ve hipertansiyon prevalansı. Ege Tıp Dergisi 2005;44(1):29-33.
16. Ünalacak M, Armutcu F, Demirel F, Gürel A, Demircan N, Aktunç E. Okul çağı çocuklarda mikroskopik idrar incelemesi ile asemptomatik bakteriüri sıklığı. Tıp Araştırmaları Dergisi 2005;3:30-2.

17. Nebigil I, Tumer N. Asymptomatic urinary tract infection in childhood. Eur J Pediatr 1992;151(4):308-9. [CrossRef]

18. Murakami M. Screening for proteinuria and hematuria in schoolchildren methods and results. Acta Paediatr Jpn 1990;32(6):682-9. [CrossRef]

19. Lin CY, Sheng CC, Lin CC, Chen CH, Chou P. Mass urinary screening and follow- up for schoolchildren in Taiwan province. Acta Paediatr Taiwan 2001;42(3):134-140.

20. Ruggenenti P, Perna A, Mosconi L, Pisoni R, Remuzzi G. Urinary protein excretion rate is the best independent predictor of ESRF in non- diabetic proteinuric chronic nephropathies. "Gruppo Italiano di Studi Epidemiological Nefrologia" (GISEN). Kidney Int 1998;53:1209-16. [CrossRef]

21. Suleymanlar G, Utas C, Arınsoy T, et al. A population based survey of chronic renal disease in Turkey - The CREDIT study. Nephrol Dial Transplant 2011;26:1862-71. [CrossRef]

22. Ambo K, Tsuchiya M, Murakami $M$, et al. Incidence of abnormalities in urinalysis in Japanese children aged six to ten years (in Japanese). J Jpn Pediatr Soc 1999;103:543-8.

23. Murakami M, Hayakawa M, Yanagihara T, Hukunaga Y. Proteinuria screening for children. Kidney Int Suppl 2005;(94):23-7. [CrossRef]

24. Ates K. Türkiye'de Nefroloji, Diyaliz ve Transplantasyon Registry 2017. Available from URL: http://www.nefroloji.org. tr/folders/file/18104_REGISTRY2017_kontrol_v1.pdf

25. Lin $C Y$, Hsieh CC, Chen WP, Yang LY, Wang HH. The underlying diseases and follow-up in Taiwanese children screened by urinalysis. Pediatr Nephrol 2001;16:232-7. [CrossRef]

26. Yap HK, Quek CM, Shen Q, Chia KS. Role of Urinary Screening Programmes in Children in the Prevention of Chronic Kidney Disease. Ann Acad Med Singapore 2005;34:3-7

27. Zainal D, Baba A, Mustaffa BE. Screening proteinuria and haematuria in Malaysian Children. SoutheastAsian J Trop Med Public Health 1995;26:785-8.

28. Cho BS, Hahn WH, Cheong HI, Lim I, Ko CW, Kim SY, Suh JS. A nation wide study of mass urine screening tests on Korean school children and implications for chronic kidney disease management. Clin Exp Nephrol 2013;17(2):205-10. [CrossRef]

29. Vernon S, Lundblad B, Hellstrom AL. Children's experiences of school toilets present a risk to their physicaland psychological health. Child Care Health Dev 2003;29:47-53. [CrossRef] 